\title{
Interspecific variation in photosynthesis and respiration balance of three seagrasses in relation to light availability
}

\author{
Yoshiyuki Tanaka ${ }^{1, *}$, Masahiro Nakaoka $^{2}$ \\ ${ }^{1}$ Ocean Research Institute, University of Tokyo, Minamidai 1-15-1, Nakano, Tokyo 164-8639, Japan \\ ${ }^{2}$ Graduate School of Science and Technology, Chiba University, Yayoi-cho 1-33, Inage, Chiba 263-8522, Japan
}

\begin{abstract}
Low light levels are a major factor determining the depth distribution of submerged macrophytes. In the Indo-Pacific tropical region, different seagrass species have specific zonation patterns from intertidal to subtidal areas along depth and light gradients. Cymodocea serrulata generally occurs in deeper water than Thalassia hemprichii and C. rotundata, suggesting that C. serrulata probably has the lowest minimum photon requirement of the 3 species. We compared photosynthesis and respiration balances of these 3 tropical seagrasses by examining photosynthesis-irradiance (P-E) curves for leaves and for the whole plant bodies. Sample collection and measurement were conducted on 2 occasions (July and February) on Ishigaki Island, southwestern Japan. Leaf photosynthetic traits were not concordant with the observed zonation pattern of the species. When respiration rates of the root and rhizome were taken into account, $T$. hemprichii had a significantly higher light compensation point (158.1 $\mu \mathrm{mol}$ photons $\mathrm{m}^{-2} \mathrm{~s}^{-1}$ in July, 187.2 in February) than C. rotundata (47.9 in July, 41.0 in February) and C. serrulata (85.1 in July, 40.0 in February). The large amount of belowground respiration in $T$. hemprichii was a major cause of the variation in the compensation irradiance. This result is in concordance with the realized distribution pattern of $T$. hemprichii, which is sparse under low light conditions caused by depth or heavy siltation. Conversely, C. serrulata had less belowground biomass and a smaller respiration demand, enabling the species to maintain a better photosynthetic/respiration balance under lower light. C. rotundata had a lower saturating irradiance, a lower compensation point and a lower respiration rate than the other species. Thus, $C$. rotundata has the potential to inhabit the deepest water, although its realized distribution range is shallower than that of $C$. serrulata, suggesting that other factors limit the depth range of $C$. rotundata.
\end{abstract}

KEY WORDS: Biomass allocation $\cdot$ Depth limit $\cdot \mathrm{O}_{2}$ budget $\cdot \mathrm{P}-\mathrm{E}$ curve $\cdot$ Tropical seagrasses

\section{INTRODUCTION}

Seagrass beds in the Indo-Pacific tropical region characteristically comprise a mixed vegetation with high species diversity. Generally, depth distributions vary among species, leading to specific zonation patterns from intertidal to subtidal areas (Mukai et al. 1987, Lee Long et al. 1993, Björk et al. 1999, De Troch et al. 2001, Tanaka \& Nakaoka 2004, Tanaka \& Kayanne 2007). For subtidal seagrass beds, light inten- sity is a major factor determining species' depth distributions (Duarte 1991). Interspecific variation in tolerance to light limitation is thought to be related to the ability (photosynthetic) of each species to maintain a positive whole-plant carbon balance. Photosynthetic traits of seagrasses, such as maximum photosynthetic rate, photosynthetic efficiency $(\alpha)$ and light compensation point may vary among species in ways similar to the patterns of sun and shade plants in terrestrial ecosystems (Larcher 2002). Even when photosynthetic 
traits do not vary, the allocation patterns of aboveground and belowground biomass may affect the $\mathrm{O}_{2}$ balance of the whole plant, leading to different depth limits among species. For example, a smaller proportion of belowground biomass is thought to enable Halophila spp. to survive in deeper and darker sites, because of its smaller respiratory demand (Dennison 1987, Duarte 1991). To determine the whole plant minimum photon requirements, it is necessary to measure the photosynthesis and/or respiration rates of both aboveground and belowground parts. However, as Hemminga (1998) pointed out, only a few studies have measured respiration in belowground parts of seagrasses (Fourqurean \& Zieman 1991, Dunton \& Tomasko 1994, Dunton 1996, Herzka \& Dunton 1998).

Thalassia hemprichii, Cymodocea rotundata and $C$. serrulata are dominant medium-sized seagrass species in tropical seagrass beds in Indo-Pacific coastal areas (Tanaka 2004). Leaf production and respiration of these 3 species have been studied using 3 major methods: (1) oxygen probes (Agawin et al. 1996, 2001, Vermaat et al. 1997, Abu Hena et al. 2001), (2) Diving-PAM (Hanelt et al. 1994, Björk et al. 1999, Haynes et al. 2000, Schwarz et al. 2000, Liu et al. 2005), and (3) gas-volume measurements (Pollard \& Moriarty 1991, Pollard \& Greenway 1993). However, there were no consistent tendencies in photosynthetic traits. To our knowledge, there have been no previous studies examining the photosynthesis-respiration balance of whole plants of these 3 species, or for any seagrass species in the Indo-Pacific tropical region. Comparisons of whole-plant $\mathrm{O}_{2}$ balance may explain the differentiated depth distributions.

The objective of this study was to quantify the whole-plant minimum photon requirements by comparing photosynthetic characteristics among the 3 seagrass species in order to determine whether light could be a factor causing the interspecific differences in depth distribution. Firstly, we measured photosynthesis and respiration for each part of the shoot. Secondly, we measured the aboveground and belowground biomass allocation of each species. Thirdly, we calculated and compared the whole-plant $\mathrm{O}_{2}$ balances of the 3 species along a light gradient.

\section{MATERIALS AND METHODS}

Environmental measurement. This study was conducted at Shiraho on Ishigaki Island in the Ryukyu Islands group, southwestern Japan (24\%21'N, $124^{\circ} 15^{\prime} \mathrm{E}$; see Tanaka \& Nakaoka 2004 for more detailed information on the study site). Sampling and experiments were performed on 2 occasions (July 2001 and February 2002). A data logger-type underwater quantum cosine sensor (MPQ-1, Sanyo-Sokki) and thermometer (MWQ-3, Sanyo-Sokki) were installed at canopy height (100 $\mathrm{cm}$ below mean sea level) during 2 periods: from 29 June to 21 July 2001 and 1 February to 25 February 2002. Photon doses (photon irradiance $x$ time) were calculated based on data taken by the data logger-type sensor. The light attenuation coefficient $\left(\mathrm{K}_{d} \mathrm{~m}^{-1} \pm \mathrm{SE}\right)$ was $0.60 \pm 0.04$ in this study site (Tanaka \& Nakaoka 2006). Therefore, at sampling depth (100 cm below mean sea level), light intensity was about half of that at the surface.

Photosynthesis-respiration measurements. Three dominant seagrass species, Thalassia hemprichii, Cymdocea rotundata and C. serrulata were collected at the same depth (about $100 \mathrm{~cm}$ below mean sea level). Shoots with the belowground parts were kept in outdoor containers with circulating seawater. Photosynthesis and respiration measurements were performed within $48 \mathrm{~h}$ of sampling. Immediately preceding the start of the experiment, leaf segments were cut at 2 to $9 \mathrm{~cm}$ from the bases of the second youngest leaves of shoots. Photosynthesis and respiration were measured using a differential gas-volumeter (Productmeter, see Yokohama et al. 1986, Abe et al. 2001) in a dark room. Measurements of $\mathrm{O}_{2}$ evolution of leaves were conducted between dawn and sunset. Water temperatures in the gas-volumeter were almost the same as those at the sampling site (within $1.4^{\circ} \mathrm{C}$ ). A halogen lamp (150 W) was used as a light source. Photosynthetically active radiation (PAR) was measured using a submersible photon irradiance sensor (192SA, Li-Cor). The $\mathrm{O}_{2}$ evolution of each leaf was measured successively at 8 levels of photon flux, viz. approximately 0 , $30,45,60,90,150,300$ and $600 \mu \mathrm{mol} \mathrm{m} \mathrm{m}^{-2} \mathrm{~s}^{-1}$. After measurement of $\mathrm{O}_{2}$ evolution, leaves were dried at $105^{\circ} \mathrm{C}$ for more than $24 \mathrm{~h}$, and their dry weights were measured. Respiration rates of roots and horizontal rhizomes were measured in darkness. Photosynthesisirradiance (P-E) curves were fitted to the data using the equation of Chalker (1981):

$$
P_{\text {net }}=P_{\max } \times \tanh \left(E / E_{\mathrm{k}}\right)+R_{\mathrm{d}}
$$

where $P_{\max }$ is the maximum photosynthetic rate, $E_{\mathrm{k}}$ is the saturating irradiance (a constant determined by the initial slope and $\left.P_{\max }\right), R_{\mathrm{d}}$ is the dark respiration rate, and $E$ is photon irradiance. The light compensation point $\left(E_{\mathrm{c}}\right)$ was determined as light intensity at which the net photosynthetic rate $\left(P_{\text {net }}\right)=$ zero. The photosynthetic efficiency $(\alpha)$ was calculated as the initial linear slope of the photosynthetic response to light.

Estimation of whole-plant $\mathrm{O}_{2}$ balance. To estimate the relationship between $\mathrm{O}_{2}$ balance and light intensity at the whole plant level, the allocation of aboveground and belowground biomass was measured for each species. Samples for biomass allocation were col- 


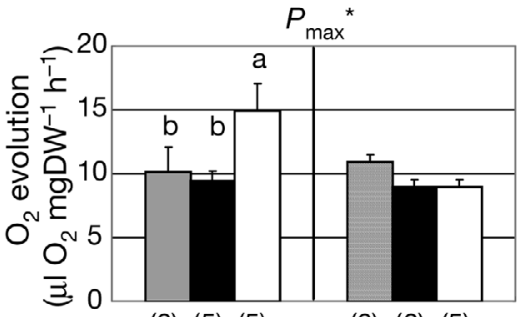

(6) (5) (5)

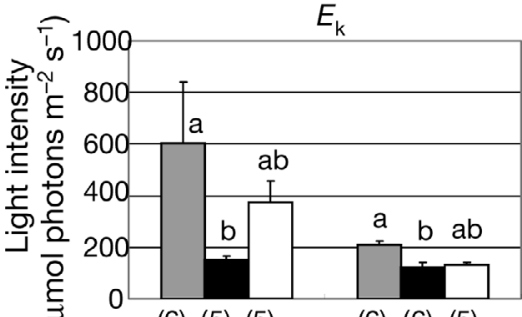

(6) (5) (5)

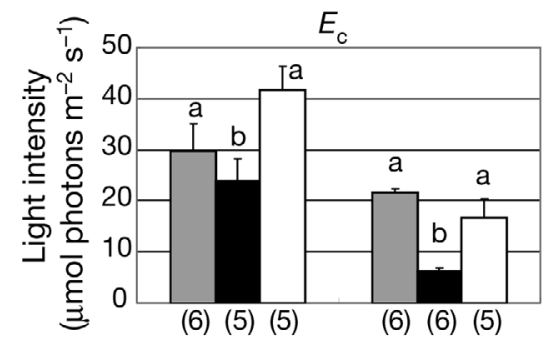

旅 $\overparen{T}$

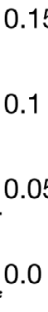

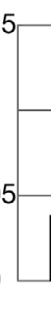
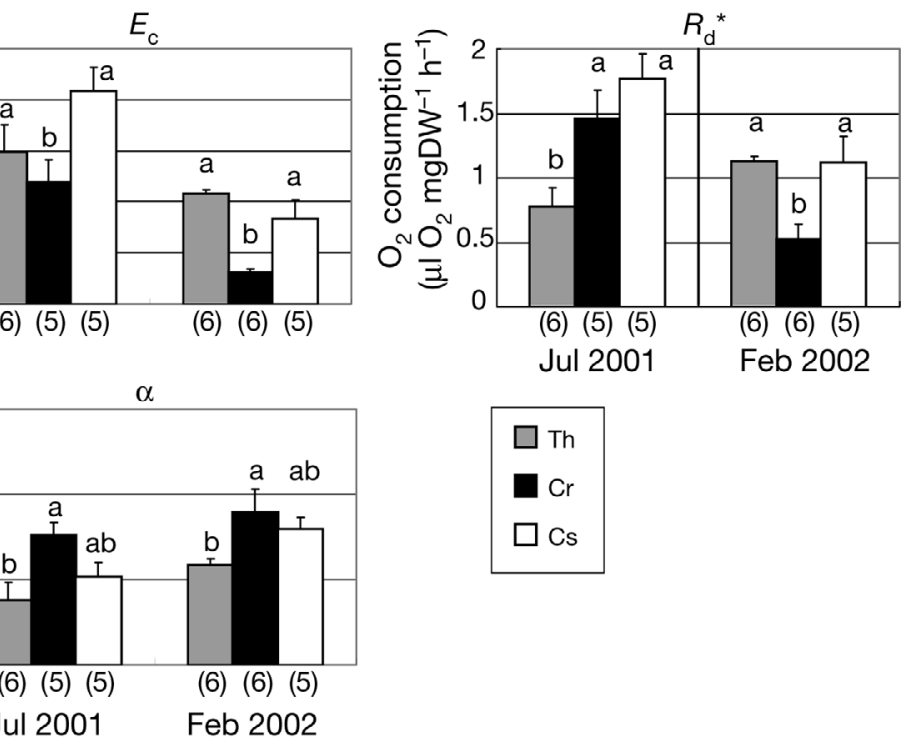

Fig. 1. Thalassia hemprichii (Th), Cymodocea rotundata (Cr), Cymodocea serrulata (Cs). Comparison of photosynthetic traits of leaf among species and seasons. Means + SE. Maximum photosynthetic rate $\left(P_{\max }\right)$, saturating photon irradiance $\left(E_{\mathrm{k}}\right)$, compensation point $\left(E_{\mathrm{c}}\right)$, respiration rate $\left(R_{\mathrm{d}}\right)$ and initial slope $(\alpha)$. Numbers in parentheses show sample sizes. Asterisk and dividing line between seasons for $P_{\max }$ and $R_{\mathrm{d}}$ indicate the existence of significant interactions in 2-way ANOVA. Different letters denote pairs of treatments for which significant variation was detected by post-hoc comparisons (Tukey's) whole plant were tested using 2-way analysis of variance (ANOVA). The respiration of belowground parts (rhizome and root) was also tested using 2-way ANOVA. Prior to ANOVA, heterogeneity of variance was tested using Cochran's C test. When the variances were heterogeneous, data were log-transformed. When significant variation was detected by ANOVA, post-hoc comparisons were performed using Tukey's test. When significant interactions were detected in 2-way ANOVA, 1-way ANOVA and multiple comparisons of means were conducted separately for each season by Tukey's test using mean square of residuals of original 2-way ANOVAs (Day \& Quinn 1989, Quinn \& Keough 2002).

\section{RESULTS}

\section{Light and temperature}

The photon dose (photon irradiance $\times$ time) was relatively high in July $\left(16.6 \pm 4.3 \mathrm{~mol} \mathrm{~m}^{-2} \mathrm{~d}^{-1} \pm \mathrm{SD}\right)$ and low in February $\left(14.3 \pm 6.5 \mathrm{~mol} \mathrm{~m}^{-2}\right.$ $\mathrm{d}^{-1}$ ), although seasonal variation was not apparent. Water temperature was high in July $\left(30.6 \pm 1.2^{\circ} \mathrm{C}\right)$ and low in February $\left(20.0 \pm 1.7^{\circ} \mathrm{C}\right)$.

\section{Photosynthetic traits of leaves}

lected using a stainless corer (diameter $20 \mathrm{~cm}$, height $50 \mathrm{~cm}$ ) in July 2001 and February 2002. Three cores were collected for each species. The samples were washed gently in fresh water and separated into 6 parts: leaf, live sheath, dead sheath, vertical rhizome, horizontal rhizome, and root. After drying at $105^{\circ} \mathrm{C}$ for more than $24 \mathrm{~h}$, the weight of each part was measured.

Whole-plant $\mathrm{O}_{2}$ balances were calculated for each core sample (3 replicates) by multiplying the biomass of each part by the average production and respiration rates per part at each light level. Because respiration rates of vertical rhizomes and live sheaths were not measured, we used data for horizontal rhizomes and leaves, respectively. Dead sheaths were eliminated from the calculations. The P-E curve for the whole plant was fitted, and $P_{\text {max }}, E_{\mathrm{k}}, E_{\mathrm{C}}, R_{\mathrm{d}}$ and $\alpha$ were determined as described above.

Statistical analyses. Interspecific and seasonal variation in $P_{\text {max }}, E_{\mathrm{k}}, E_{\mathrm{C}}, R_{\mathrm{d}}$ and $\alpha$ of leaf parts and of the
P-E curves of leaves varied among species and seasons (Fig. 1). For the maximum photosynthetic rate $\left(P_{\max }, \mu \mathrm{O} \mathrm{O}_{2} \mathrm{mgDW}^{-1}\right.$ hour $\left.^{-1}\right)$, the species $\times$ season interaction was significant (Table 1). Post-hoc comparisons revealed that in July, $P_{\max }$ of Cymodocea serrulata was significantly higher than those of Thalassia hemprichii and $C$. rotundata (1-way ANOVA, $F_{2,27}=5.1, \mathrm{p}=0.01$ ). Post-hoc comparisons revealed that in February, amongspecies variation in $P_{\max }$ was not significant (1-way ANOVA, $\left.F_{2,27}=0.8, \mathrm{p}=0.45\right)$.

Saturating photon irradiance $\left(E_{\mathrm{k}}, \mu \mathrm{mol}\right.$ photons $\mathrm{m}^{-2}$ $\mathrm{s}^{-1}$ ) was significantly lower in February than in July. Post-hoc comparison showed that Cymodocea rotundata had a significantly lower $E_{\mathrm{k}}$ than Thalassia hemprichii (Fig. 1, Table 1).

The light compensation point $\left(E_{\mathrm{C}}, \mu \mathrm{mol}\right.$ photons $\mathrm{m}^{-2}$ $\mathrm{s}^{-1}$ ) was significantly lower in February than in July. Post-hoc comparison revealed that Cymodocea rotun- 
data had a significantly lower $E_{\mathrm{C}}$ than the other 2 species (Fig. 1, Table 1).

A significant species $\times$ season interaction was found for leaf dark respiration $\left(R_{\mathrm{d}}, \mu \mathrm{l} \quad \mathrm{O}_{2} \quad \mathrm{mgDW}^{-1} \mathrm{~h}^{-1}\right.$; Table 1). Post-hoc comparisons revealed that in July, $R_{\mathrm{d}}$ of Thalassia hemprichii was significantly lower than those of Cymodocea rotundata and C. serrulata (1-way

Table 1. Thalassia hemprichii, Cymodocea rotundata, C. serrulata. Two-way ANOVA for photosynthetic traits of leaves: maximum photosynthetic rate $\left(P_{\max }\right)$, saturating irradiance $\left(E_{\mathrm{k}}\right)$, compensation point $\left(E_{\mathrm{c}}\right)$, respiration rate $\left(R_{\mathrm{d}}\right)$ and initial slope $(\alpha)$. The data for $E_{\mathrm{k}}$ were log-transformed to reduce heterogeneity of variances

\begin{tabular}{|lrrrr|}
\hline & df & MS & $F$ & $p$ \\
\hline $\boldsymbol{P}_{\text {max }}$ & & & & \\
Species & 2 & 20.4 & 2.3 & 0.12 \\
Season & 1 & 24.0 & 2.7 & 0.11 \\
Species $\times$ Season & 2 & 33.5 & 3.7 & 0.04 \\
Error & 27 & 9.0 & & \\
$\boldsymbol{E}_{\mathbf{k}}$ & & & & \\
Species & 2 & 1.7 & 4.7 & 0.02 \\
Seasons & 1 & 2.8 & 7.5 & 0.01 \\
Species $\times$ Season & 2 & 0.3 & 0.8 & 0.46 \\
Error & 27 & 0.4 & & \\
$\boldsymbol{E}_{\mathbf{c}}$ & & & & \\
Species & 2 & 673.8 & 8.9 & $<0.01$ \\
Seasons & 1 & 2223.3 & 29.5 & $<0.01$ \\
Species $\times$ Season & 2 & 193.6 & 2.6 & 0.10 \\
Error & 27 & 75.4 & & \\
$\boldsymbol{R}_{\mathbf{d}}$ & & & & \\
Species & 2 & 0.9 & 6.2 & $<0.01$ \\
Seasons & 1 & 1.2 & 8.7 & $<0.01$ \\
Species $\times$ Season & 2 & 1.3 & 9.6 & $<0.01$ \\
Error & 27 & 0.1 & & \\
$\boldsymbol{\alpha}$ & & & & \\
Species & 2 & $3.5 \times 10^{-3}$ & 7.0 & $<0.01$ \\
Seasons & 1 & $3.5 \times 10^{-3}$ & 7.1 & 0.01 \\
Species $\times$ Season & 2 & $1.3 \times 10^{-4}$ & 0.3 & 0.77 \\
Error & 27 & $5.0 \times 10^{-4}$ & & \\
\hline & & & & \\
\hline
\end{tabular}

ANOVA, $F_{2,27}=10.4, \mathrm{p}<0.01$; Fig. 1). Post-hoc comparisons revealed that in February, $R_{\mathrm{d}}$ of $C$. rotundata was significantly lower than those of $T$. hemprichii and C. serrulata (1-way ANOVA, $F_{2,27}=5.1, \mathrm{p}=0.01$; Fig. 1).

The photosynthetic efficiency $\left[\alpha, \quad\left(\mu l \mathrm{O}_{2} \mathrm{mgDW}^{-1}\right.\right.$ $\left.\mathrm{h}^{-1}\right) /\left(\mu \mathrm{mol}\right.$ photons $\left.\mathrm{m}^{-2} \mathrm{~s}^{-1}\right)$ ] was significantly higher in February than in July. Post-hoc comparison showed that Cymodocea rotundata had a significantly higher $\alpha$ than Thalassia hemprichii (Fig. 1, Table 1).

\section{Respiration of belowground parts}

The consumption of $\mathrm{O}_{2}$ per unit mass $\left(R_{\mathrm{d}}, \mu \mathrm{O} \mathrm{O}_{2}\right.$ $\mathrm{mgDW}^{-1} \mathrm{~h}^{-1}$ ) was greater in roots than in rhizomes for

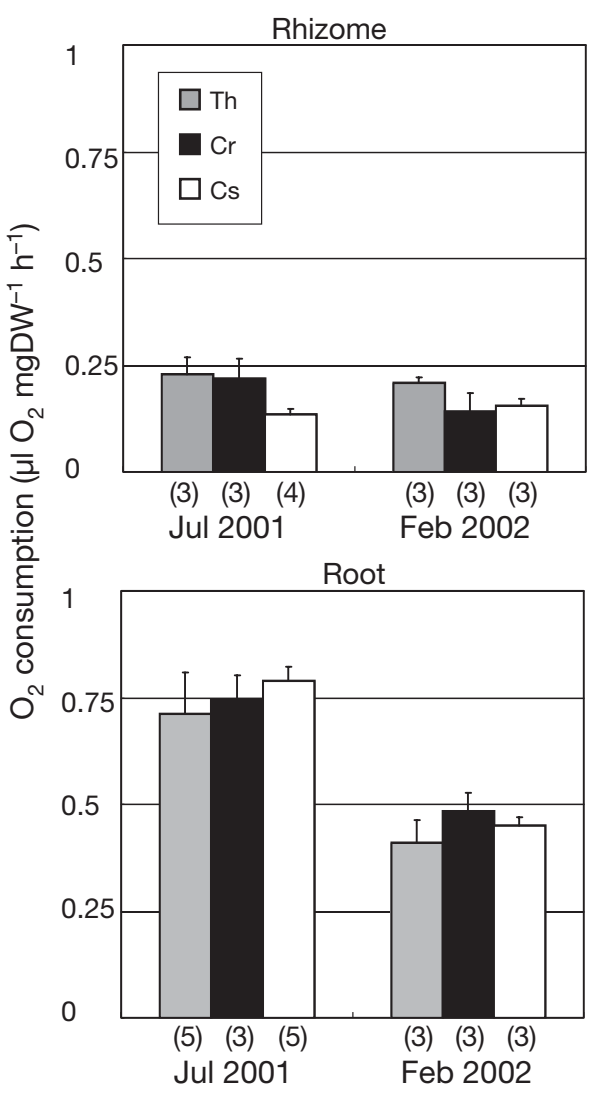

Fig. 2. Thalassia hemprichii (Th), Cymodocea rotundata $(\mathrm{Cr})$, Cymodocea serrulata (Cs). Interspecific and seasonal variation in respiration of rhizome and root. Means + SE. Numbers in parentheses are sample sizes

all species and seasons (Fig. 2). There were no significant differences in rhizome $R_{\mathrm{d}}$ among species or seasons (Table 2). Root $R_{\mathrm{d}}$ was significantly greater in July than in February. Among-species variation in root $R_{\mathrm{d}}$ was not significant (Table 2).

Table 2. Thalassia hemprichii, Cymodocea rotundata, C. serrulata. Two-way ANOVA for respiration rate of rhizome and root. Data for roots were log-transformed to reduce heterogeneity of variances

\begin{tabular}{|lrcrr|}
\hline & df & MS & $F$ & p \\
\hline Rhizome & & & & \\
Species & 2 & $8.9 \times 10^{-3}$ & 3.1 & 0.08 \\
Season & 1 & $2.5 \times 10^{-3}$ & 0.8 & 0.37 \\
Season $\times$ Species & 2 & $3.6 \times 10^{-3}$ & 1.2 & 0.32 \\
Error & 13 & $2.9 \times 10^{-3}$ & & \\
Root & & & & \\
Species & 2 & $3.0 \times 10^{-2}$ & 0.9 & 0.41 \\
Season & 1 & 1.4 & 43.7 & $<0.01$ \\
Season $\times$ Species & 2 & $6.7 \times 10^{-3}$ & 0.2 & 0.81 \\
Error & 16 & $3.2 \times 10^{-2}$ & & \\
\hline
\end{tabular}




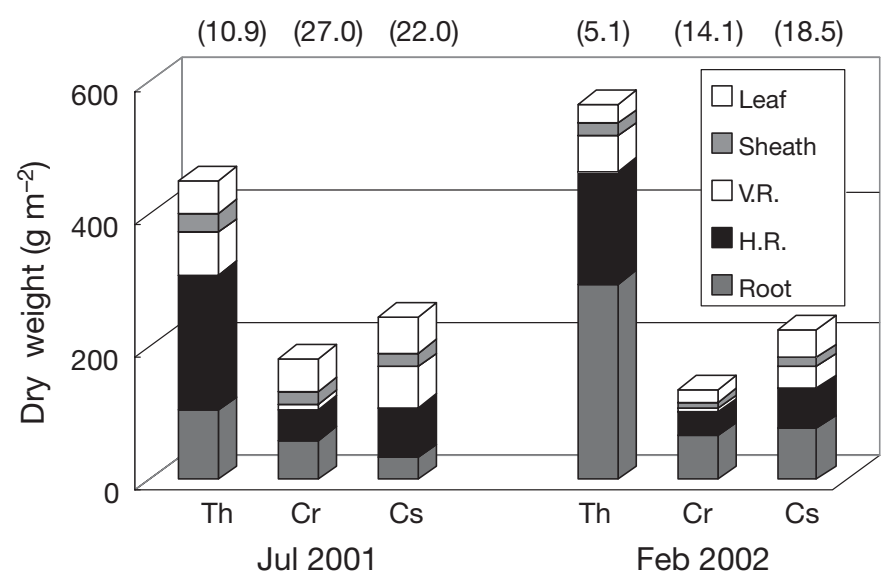

Fig. 3. Thalassia hemprichii (Th), Cymodocea rotundata $(\mathrm{Cr})$, Cymodocea serrulata (Cs). Comparison of mean biomass allocations among species and seasons. $\mathrm{n}=3$ cores, V.R. = vertical rhizome, H.R. = horizontal rhizome. Numbers in parentheses are the ratios of leaf biomass to whole-plant biomass (\%) (1-way ANOVA, $\left.F_{2,12}=4.32 \times 10^{6}, \mathrm{p}<0.01\right)$. Posthoc comparisons revealed that in February, $E_{\mathrm{k}}$ of T. hemprichii was highest, followed by C. serrulata and then $C$. rotundata (1-way ANOVA, $F_{2,12}=$ $\left.1.03 \times 10^{6}, \mathrm{p}<0.01\right)$.

There was a significant species $\times$ season interaction for light compensation point $\left(E_{\mathrm{C}}, \mu \mathrm{mol}\right.$ photons $\mathrm{m}^{-2} \mathrm{~s}^{-1}$, Table 3). Post-hoc comparisons revealed that in July, $E_{\mathrm{c}}$ of Thalassia hemprichii was higher than those of Cymodocea serrulata and $C$. rotundata (1-way ANOVA, $F_{2,12}=19.7, \mathrm{p}<$ 0.01, Fig. 4). Post-hoc comparisons revealed that in February, $E_{\mathrm{c}}$ of $T$. hemprichii was $>4$ times higher than those of the other 2 species (1-way ANOVA, $F_{2,12}=45.1, \mathrm{p}<0.01$, Fig. 4 ).

There was no significant difference in dark respiration $\left(R_{\mathrm{d}}, \mu \mathrm{O} \mathrm{O}_{2} \mathrm{mgDW}^{-1} \mathrm{~h}^{-1}\right)$ between seasons (Table 3 ). $R_{\mathrm{d}}$ of Thalassia hemprichii was significantly greater than that of Cymodocea rotundata.

\section{Biomass allocation}

Thalassia hemprichii had the largest total biomass per area, followed by Cymodocea serrulata and C. rotundata in that order (Fig. 3). The proportion of total biomass contributed by leaves was smallest for T. hemprichii in both July and February (Fig. 3). The relative leaf biomass decreased in February for all species.

\section{Whole-plant $\mathrm{O}_{2}$ balance}

The relationship between light intensity and whole-plant photosynthesis-respiration balance varied among species and seasons (Fig. 4). The maximum photosynthetic rates $\left(P_{\text {max }}, \mu l \mathrm{O}_{2}\right.$ mgDW $\left.^{-1} \mathrm{~h}^{-1}\right)$ were significantly reduced in February compared to those in July. Post-hoc comparisons revealed that Cymodocea rotundata had a significantly lower $P_{\max }$ than C. serrulata (Fig. 4, Table 3).

Saturating irradiance $\left(E_{k}\right.$, $\mu \mathrm{mol}$ photons $\mathrm{m}^{-2} \mathrm{~s}^{-1}$ ) showed a significant species $\times$ season interaction (Table 3 ). Post-hoc comparisons revealed that in July, $E_{\mathrm{k}}$ of Cymodocea serrulata was highest, followed by Thalassia hemprichii and then $C$. rotundata
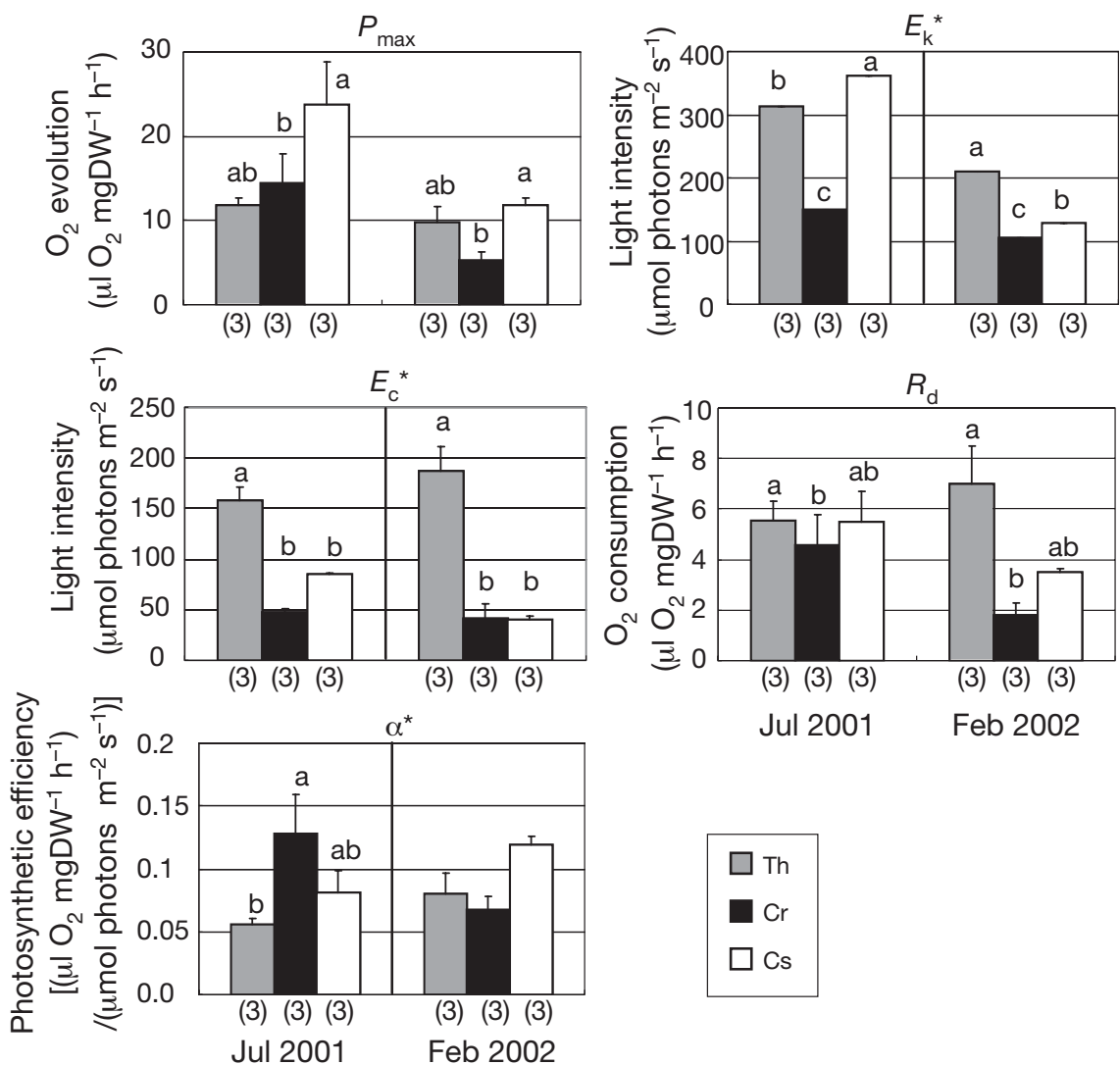

(3) (3) (3)

(3) (3) (3)

Jul 2001

Feb 2002

Fig. 4. Thalassia hemprichii (Th), Cymodocea rotundata (Cr), Cymodocea serrulata (Cs). Comparison of photosynthetic traits at whole-plant level among species and seasons. Means + SE. Maximum photosynthetic rate $\left(P_{\max }\right)$, saturating irradiance $\left(E_{\mathrm{k}}\right)$, compensation point $\left(E_{\mathrm{c}}\right)$, respiration rate $\left(R_{\mathrm{d}}\right)$ and initial slope $(\alpha)$. Numbers in parentheses show sample sizes. Asterisk and dividing line of seasons for $E_{\mathrm{k}}, E_{\mathrm{c}}$ and $\alpha$ indicate existence of significant interactions in 2-way ANOVA. Different letters denote pairs of treatments for which significant variation was detected by post-hoc comparisons (Tukey's) 
Table 3. Thalassia hemprichii, Cymodocea rotundata, C. serrulata. Two-way ANOVA for whole plant photosynthesis and respiration balance: maximum photosynthetic rate $\left(P_{\max }\right)$, saturating irradiance $\left(E_{\mathrm{k}}\right)$, compensation point $\left(E_{\mathrm{c}}\right)$, respiration rate $\left(R_{\mathrm{d}}\right)$ and initial slope $(\alpha)$

\begin{tabular}{|c|c|c|c|c|}
\hline & $\mathrm{df}$ & MS & $F$ & $\mathrm{p}$ \\
\hline \multicolumn{5}{|l|}{$\boldsymbol{P}_{\max }$} \\
\hline Species & 2 & 110.6 & 5.1 & 0.03 \\
\hline Season & 1 & 266.7 & 12.2 & $<0.01$ \\
\hline Species $\times$ Season & 2 & 40.0 & 1.8 & 0.20 \\
\hline Error & 12 & 21.9 & & \\
\hline \multicolumn{5}{|l|}{$E_{\mathrm{k}}$} \\
\hline Species & 2 & $3.2 \times 10^{4}$ & $3.71 \times 10^{6}$ & $<0.01$ \\
\hline Season & 1 & $7.3 \times 10^{4}$ & $8.42 \times 10^{6}$ & $<0.01$ \\
\hline Species $\times$ Season & 2 & $1.4 \times 10^{4}$ & $1.64 \times 10^{6}$ & $<0.01$ \\
\hline Error & 12 & $8.6 \times 10^{-3}$ & & \\
\hline \multicolumn{5}{|l|}{$E_{\mathrm{c}}$} \\
\hline Species & 2 & $2.9 \times 10^{4}$ & 60.5 & $<0.01$ \\
\hline Season & 1 & $2.6 \times 10^{2}$ & 0.5 & 0.47 \\
\hline Species $\times$ Season & 2 & $2.1 \times 10^{3}$ & 4.3 & 0.04 \\
\hline Error & 12 & $4.8 \times 10^{2}$ & & \\
\hline \multicolumn{5}{|l|}{$\boldsymbol{R}_{\mathrm{d}}$} \\
\hline Species & 2 & 14.2 & 4.6 & 0.03 \\
\hline Season & 1 & 5.4 & 1.7 & 0.21 \\
\hline Species $\times$ Season & 2 & 7.6 & 2.5 & 0.13 \\
\hline Error & 12 & 3.1 & & \\
\hline \multicolumn{5}{|l|}{$\alpha$} \\
\hline Species & 2 & $1.9 \times 10^{-3}$ & 2.2 & 0.15 \\
\hline Season & 1 & $3.4 \times 10^{-6}$ & $3.9 \times 10^{-3}$ & 0.95 \\
\hline Species $\times$ Season & 2 & $4.3 \times 10^{-3}$ & 5.0 & 0.03 \\
\hline Error & 12 & $8.6 \times 10^{-4}$ & & \\
\hline
\end{tabular}

The photosynthetic efficiency $\left[\alpha, \quad\left(\mu l \mathrm{O}_{2} \mathrm{mgDW}^{-1}\right.\right.$ $\left.\mathrm{h}^{-1}\right) /\left(\mu \mathrm{mol}\right.$ photons $\left.\mathrm{m}^{-2} \mathrm{~s}^{-1}\right)$ ] showed a significant species $\times$ season interaction (Table 3 ). In July, $\alpha$ of Cymodocea rotundata was highest, followed by C. serrulata and then Thalassia hemprichii (1-way ANOVA, $F_{2,12}=4.7, p=0.03$, Fig. 4). In February, among-species variation in $\alpha$ was not significant (1-way ANOVA, $F_{2,12}=2.5, \mathrm{p}=0.12$, Fig. 4).

\section{DISCUSSION}

The photosynthesis-respiration balance in Thalassia hemprichii shifted significantly towards respiration in low light conditions, as shown by the significantly higher light compensation point of this species for both seasons compared to those of the other 2 species (when root and rhizome respiration were taken into account). This difference among species was not observed when we compared the $\mathrm{O}_{2}$ budgets per leaf. Thus the interspecific variations cannot be ascribed fully to differences in leaf characteristics. The high light compensation point of $T$. hemprichii is due to its large belowground biomass, which has high respiratory demand. The present study demonstrates that wholeplant evaluations are essential in identifying differences in $\mathrm{O}_{2}$ budgets among seagrass species.

These results are in accordance with the actual distribution pattern of Thalassia hemprichii, which is not dominant in deeper, darker locations (Table 4). The species is also sparse in sites with high silt and clay content in the sediment, where light penetration is reduced (Bach et al. 1998, Terrados et al. 1998). In contrast, T. hemprichii is dominant in shallow waters where light conditions are more suitable (Duarte et al. 2000, Tanaka \& Kayanne 2007). A possible explanation for its dominance may relate to its large belowground biomass. The ratio of leaf biomass to whole-plant biomass of $T$. hemprichii was lowest among the 3 species in both July (10.9\%) and February (5.1\%). The observed ratio for the Ishigaki Island population falls within the typical ranges of this species and the congeneric T. testudinum, e.g. between 5.7 and $10.8 \%$ for T. hemprichii in Papua New Guinea (Brouns 1985), and between 5 and $13 \%$ for T. testudinum in Texas, USA (Herzka \& Dunton 1998). T. hemprichii is a good competitor for nutrients, because its roots can reach deeper into the substratum to acquire nutrients that other species can not access (Duarte et al. 1998). This trade-off between the $\mathrm{O}_{2}$ budget and nutrient acquisition of the large belowground biomass may determine species occurrence and abundance across environmental gradients such as depth.

In previous studies, the long vertical rhizome of Cymodocea serrulata was considered to be advantageous for light acquisition, and for preventing the plant from being buried by sediment, because it enables the canopy to reach higher into the water column (Vermaat et al. 1997, Duarte et al. 1997, Bach et al. 1998, Terrados et al. 1998). Here, we showed that the small belowground biomass of $C$. serrulata had a small respiratory demand, which enables the species to survive in environments with low light intensity (as shown by lower light compensation point compared to that of Thalassia hemprichii). These morphological traits (i.e. reduced belowground biomass and long vertical rhizomes) may both contribute to the dominance of C. serrulata in deep habitats.

In the present study, Cymodocea rotundata had a lower saturating irradiance, lower light compensation point, and lower respiration rate than other species when compared on a whole-plant basis. This suggests that $C$. rotundata has the potential to grow at greater depths than the other species. However, the realized distribution range of $C$. rotundata is shallower than that of C. serrulata (Table 4). This discrepancy suggests that factors other than photosynthetic ability and whole-plant $\mathrm{O}_{2}$ balance under low light conditions limit the occurrence of $C$. rotundata in deep water. 
Table 4. Thalassia hemprichii (Th), Cymodocea rotundata (Cr), C. serrulata (Cs). Comparison of lower depth limit (LDL) and mean or dominant depth of occurrence (MDDO)

\begin{tabular}{|c|c|c|c|c|}
\hline \multirow[t]{2}{*}{ Location } & \multicolumn{3}{|c|}{ LDL/MDDO } & \multirow[t]{2}{*}{ Source } \\
\hline & Th & $\mathrm{Cr}$ & Cs & \\
\hline Australia: between Cape York and Hervey Bay & $3.2 \mathrm{~m} / 1.7 \mathrm{~m}^{\mathrm{a}}$ & $3.6 \mathrm{~m} / 1.4 \mathrm{~m}$ & $18.0 \mathrm{~m} / 4.6 \mathrm{~m}$ & Lee Long et al. (1993) \\
\hline The Phillipines: Silaqui Island & $3.0 \mathrm{~m} / 0.0 \mathrm{~m}^{\mathrm{b}}$ & $1.0 \mathrm{~m} / 0.5 \mathrm{~m}$ & $3.0 \mathrm{~m} / 1.0 \mathrm{~m}$ & Bach et al. (1998) \\
\hline Tanzania: Zanzibar & Shallow & Shallow & Deep & Björk et al. (1999) \\
\hline Japan: Ishigaki Island & $2.2 \mathrm{~m} / 1.1 \mathrm{~m}^{\mathrm{a}}$ & $2.6 \mathrm{~m} / 1.1 \mathrm{~m}$ & $3.0 \mathrm{~m} / 2.4 \mathrm{~m}$ & Tanaka \& Kayanne (2007) \\
\hline${ }^{a}$ From mean sea level, ${ }^{b}$ from mean low tide & & & & \\
\hline
\end{tabular}

Recently, it has been shown that self-shading strongly affects the production of the seagrasses (Enríquez et al. 2002, Enríquez \& Pantoja-Reyes 2005). Monsi \& Saeki (2005) compared productive structures of broad-leaf and grass type terrestrial plant communities. The broad leaf plants spread leaves horizontally, while grasses extend them vertically. Consequently, the grass type community has an advantage in community productivity, because a reduction in self shading increases the interception of solar radiation. Although Cymodocea rotundata and C. serrulata are congeners, the direction of leaf extension seems different between them. C. rotundata extends leaves rather more vertically than $C$. serrulata. Hence, the morphology of C. rotundata may be advantageous for prevention of self-shading. On the other hand, this characteristic seems inefficient for photon capture under low light conditions.

When weights per unit area $\left(\mathrm{mg} \mathrm{cm}^{-2}\right)$ of leaf samples were calculated, post-hoc comparisons revealed that of Cymodocea serrulata was significantly smaller than those of the other species both in July (1-way ANOVA, $F_{2,13}=30.9, \mathrm{p}<0.001$ ) and in February (1way ANOVA, $\left.F_{2,14}=25.6, p<0.001\right)$. Specific leaf weight $\left(\mathrm{g} \mathrm{m}^{-2}\right)$ of Zostera asiatica in northeastern Japan was smaller in a deeper site (3 $\mathrm{m}$ deep) than in a shallow site $(1.5 \mathrm{~m})$ (Watanabe et al. 2000). The small specific leaf weight of $C$. serrulata may be advantageous for survival under low-light circumstances. In this study, the illumination was projected perpendicularly toward the leaf pieces and there was no apparent difference in photosynthetic traits between $C$. rotundata and C. serrulata. However, the morphological traits may affect their photosynthetic efficiency in situ and consequently zonal distribution.

In conclusion, the present study of whole-plant photosynthesis and respiration balance in 3 medium-sized seagrass species demonstrated that the depth limit of Thalassia hemprichii can be explained by its poor photosynthesis versus respiration balance under low light conditions (due to its larger amount of non-photosynthetic biomass). On the other hand, Cymodocea serrulata can survive dark conditions because of the smaller respiratory demands of its belowground parts. However, the photosynthesis and respiration balance of $C$. rotundata did not explain its absence in deep water. In future studies, experimental approaches such as transplantation would be useful to examine the observed discrepancy between the realized distributional depth ranges of these seagrasses and those predicted from the measurements of biomass allocation and photosynthetic traits.

Acknowledgements. We thank M. Taira, H. Shimabukuro and Y. Umezawa for assistance with the field research. T. Hayashibara and other staff at the Ishigaki Tropical Station of the Seikai National Fisheries Research Institute provided laboratory equipment. H. Hata helped with the photosynthesis analysis. K. Yamada supported us with statistical discussions. H. Kayanne, I. Koike, H. Mukai and T. Miyajima provided invaluable support. We also thank K. L. Heck Jr and 3 anonymous reviewers for their constructive comments. This research was supported by a Sasakawa Scientific Research Grant (The Japan Science Society).

\section{LITERATURE CITED}

Abe S, Kurashima A, Yokohama Y, Tanaka J (2001) The cellular ability of desiccation tolerance in Japanese intertidal seaweeds. Bot Mar 44:125-131

Abu Hena MK, Misri K, Sidik BJ, Hishamuddin O, Hidir H (2001) Photosynthesis of seagrass Cymodocea serrulata (Magnoliophyta/Potamogetonales/Cymodoceaceae) in field and laboratory. Indian J Mar Sci 30:253-256

Agawin NSR, Duarte CM, Fortes MD (1996) Nutrient limitation of Philippine seagrasses (Cape Bolinao, NW Philippines): in situ experimental evidence. Mar Ecol Prog Ser 138:233-243

Agawin NSR, Duarte CM, Fortes MD, Uri JS, Vermaat JE (2001) Temporal changes in the abundance, leaf growth and photosynthesis of three co-occurring Philippine seagrasses. J Exp Mar Biol Ecol 260:217-239

Bach SS, Borum J, Fortes MD, Duarte CM (1998) Species composition and plant performance of mixed seagrass beds along a siltation gradient at Cape Bolinao, The Philippines. Mar Ecol Prog Ser 174:247-256

Björk M, Uku J, Weil A, Beer S (1999) Photosynthetic tolerances to desiccation of tropical intertidal seagrasses. Mar Ecol Prog Ser 191:121-126

Brouns JJWM (1985) A comparison of the annual production and biomass in three monospecific stands of the seagrass Thalassia hemprichii (Ehrenb.) Aschers. Aquat Bot 23: 149-175 
Chalker BE (1981) Simulating light-saturation curves for photosynthesis and calcification by reef-building corals. Mar Biol 63:135-141

Day RW, Quinn GP (1989) Comparisons of treatments after an analysis of variance in ecology. Ecol Monogr 59:433-463

Dennison WC (1987) Effects of light on seagrass photosynthesis, growth and depth distribution. Aquat Bot 27:15-26

De Troch M, Gurdebeke S, Fiers F, Vincx M (2001) Zonation and structuring factors of meiofauna communities in a tropical seagrass bed (Gazi Bay, Kenya). J Sea Res 45: 45-61

Duarte CM (1991) Seagrass depth limits. Aquat Bot 40: 363-377

Duarte CM, Terrados J, Agawin NSR, Fortes MD, Bach S, Kenworthy WJ (1997) Response of a mixed Philippine seagrass meadow to experimental burial. Mar Ecol Prog Ser 147:285-294

Duarte CM, Merino M, Agawin NSR, Uri J, Fortes MD, Gallegos ME, Marba N, Hemminga MA (1998) Root production and belowground seagrass biomass. Mar Ecol Prog Ser 171:97-108

Duarte CM, Terrados J, Agawin NSR, Fortes MD (2000) An experimental test of the occurrence of competitive interactions among SE Asian seagrasses. Mar Ecol Prog Ser 197:231-240

Dunton KH (1996) Photosynthetic production and biomass of the subtropical seagrass Halodule wrightii along an estuarine gradient. Estuaries 19:436-447

Dunton KH, Tomasko DA (1994) In situ photosynthesis in the seagrass Halodule wrightii in a hypersaline subtropical lagoon. Mar Ecol Prog Ser 107:281-293

Enríquez S, Pantoja-Reyes NI (2005) Form-function analysis of the effect of canopy morphology on leaf self-shading in the seagrass Thalassia testudinum. Oecologia 145: 235-243

Enríquez S, Merino M, Iglesias-Prieto R (2002) Variations in the photosynthetic performance along the leaves of the tropical seagrass Thalassia testudinum. Mar Biol 140: 891-900

Fourqurean JW, Zieman JC (1991) Photosynthesis, repiration and whole plant carbon budget of the seagrass Thalassia testudinum. Mar Ecol Prog Ser 69:161-170

Hanelt D, Li J, Nultsch W (1994) Tidal dependence of photoinhibition of photosynthesis in marine macrophytes of the South China Sea. Bot Acta 107:66-72

Haynes D, Ralph P, Prange J, Dennison B (2000) The impact of the herbicide diuron on photosynthesis in three species of tropical seagrass. Mar Pollut Bull 41:288-293

Hemminga MA (1998) The root/rhizome system of seagrasses: an asset and a burden. J Sea Res 39:183-196

Herzka SZ, Dunton KH (1998) Light and carbon balance in the seagrass Thalassia testudinum: evaluation of current production models. Mar Biol 132:711-721

Larcher W (2002) Physiological plant ecology. SpringerVerlag, Berlin

Lee Long WJ, Mellors JE, Coles RG (1993) Seagrasses between Cape York and Hervey Bay, Queensland, Australia. Aust J Mar Freshw Res 44:19-31

Liu SL, Wang WL, Dy DT, Fu CC (2005) The effect of ulvoid

Editorial responsibility: Kenneth Heck (Contributing Editor), Dauphin Island, Alabama, USA macroalgae on the inorganic carbon utilization by an intertidal seagrass Thalassia hemprichii. Bot Bull Acad Sinica 46:197-203

Monsi M, Saeki T (2005) On the factor light in plant communities and its importancefor matter production. Ann Bot 95:549-567

Mukai H, Nojima S, Nishihira M (1987) Seagrass coverage and distribution in Loloata seagrass bed. In: Hattori A (ed) Studies on dynamics of the biological community in tropical seagrass ecosystems in Papua New Guinea: the second report. Ocean Research Institute, University of Tokyo, Tokyo, p 18-27

Pollard PC, Greenway M (1993) Photosynthetic characteristics of seagrasses (Cymodocea serrulata, Thalassia hemprichii and Zostera capricorni) in a low-light environment, with a comparison of leaf-marking and lacunal-gas measurements of productivity. Aust J Mar Freshw Res 44: 127-139

Pollard PC, Moriarty DJW (1991) Organic carbon decomposition, primary and bacterial productivity, and sulphate reduction, in tropical seagrass beds of the Gulf of Carpentaria, Australia. Mar Ecol Prog Ser 69:149-159

Quinn GP, Keough MJ (2002) Experimental design and data analysis for biologists. Cambridge University Press, Cambridge

Schwarz AM, Björk M, Buluda T, Mtolera H, Beer S (2000) Photosynthetic utilization of carbon and light by two tropical seagrass species as measured in situ. Mar Biol 137: $755-761$

Tanaka Y (2004) Effect of physical environmental factors on community structure of tropical seagrass meadows. PhD dissertation, University of Tokyo

Tanaka Y, Kayanne H (2007) Relationship of species composition of tropical seagrass meadows to multiple physical environmental factors. Ecol Res 22:87-96

Tanaka Y, Nakaoka M (2004) Emergence stress and morphological constraints affect the species distribution and growth of subtropical intertidal seagrasses. Mar Ecol Prog Ser 284:117-131

Tanaka Y, Nakaoka M (2006) Morphological variation in the tropical seagrasses, Cymodocea serrulata and C. rotundata, in response to sediment conditions and light attenuation. Bot Mar 49:365-371

Terrados J, Duarte CM, Fortes MD, Borum J and 7 others (1998) Changes in community structure and biomass of seagrass communities along gradients of siltation in SE Asia. Estuar Coast Shelf Sci 46:757-768

Vermaat JE, Agawin NSR, Fortes MD, Uri JS, Duarte CM, Marba N, Enríquez S, van Vierssen W (1997) The capacity of seagrass to survive increased turbidity and siltation: the significance of growth form and light use. Ambio 26: 499-504

Watanabe M, Nakaoka M, Mukai H (2000) Growth and productivity of Zostera asiatica and Zostera marina in Akkeshi, northern Japan. Biol Mar Medit 7:156-159

Yokohama Y, Katayama N, Furuya K (1986) An improved type of 'Productmeter', a differential gas-volumeter, and its application to measuring photosynthesis of seaweeds. Jpn J Phycol 34:37-42 (in Japanese with English abstract)

Submitted: July 5, 2006; Accepted: May 31, 2007

Proofs received from author(s): November 6, 2007 